JURNAL AL BAYAN: JURNAL JURUSAN PENDIDIKAN BAHASA ARAB

\title{
Perception of Stake Holder About Graduates' Profile and Its Implications for Curriculum Development
}

\author{
Erlina $^{1 *}$, Khoirurrijal ${ }^{2}$, Muhbib Abdul Wahab ${ }^{3}$, Umi Hijriyah ${ }^{4}$ \\ ${ }^{1}$ Prodi Pendidikan Bahasa Arab Universitas Islam Negeri Raden Intan Lampung, Indonesia \\ ${ }^{2}$ Prodi Pendidikan Bahasa Arab Institut Agama Islam Negeri Metro Lampung, Indonesia \\ ${ }^{3}$ Prodi Pendidikan Bahasa Arab Universitas Islam Negeri Syarif Hidayatullah Jakarta, Indonesia \\ ${ }^{4}$ Prodi Pendidikan Bahasa Arab Universitas Islam Negeri Raden Intan Lampung
}

\section{Article History:}

Received : March 1st 2019

Revised : April $3^{\text {rd }}, 2019$

Accepted : May 5 ${ }^{\text {th }}, 2019$

Published : June $1^{\text {st }}, 2019$

\section{Keywords:}

Arabic; Curriculum; Education; Graduates

\section{*Correspondence Address:} erlina@radenintan.ac.id

\begin{abstract}
Master study program of Arabic Education (PBA) in UIN Raden Intan Lampung Postgraduate was established in 2017. The draft curriculum for this study program has not been reviewed and validated according to the needs of the graduates. In the curriculum, a formulation of graduates' profile is needed. This research aims to determine the perceptions of Stakeholders about the profile of master study program of Arabic Education (PBA) graduates of UIN Raden Intan Lampung is as their expectation and the demand of the IQF (Indonesian Qualification Framework) level 8 in applied master program.This research was conducted in qualitative with Survey method. Data collection instruments include questionnaires, interviews and documentation. Data is analyzed in qualitative. The survey results of stakeholders are known that the profile of the main graduates of master study program of Arabic Education (PBA) in UIN Raden Intan Lampung Postgraduate is as a teacher of Arabic in the Bachelor program (S1), supporting profiles as researchers, Arabic Education designers and the preferred profiles as Arabic philologists or journalists. The formulation of the Graduate Profile has implications for curriculum development and the preparation of the documents.
\end{abstract}

\section{Introduction}

The curriculum must be designed and developed based on philosophical, sociological, psychological factors (Nasution: 2003), the needs of students (Job Market) 'and curriculum theory. In the context of Indonesian society, the foundation of curriculum development is based on the Pancasila nation's philosophy of life, sociocultural conditions, applicable regulations, values, needs, students' psychological conditions, the needs, and demands of the public.

Along with macro changes in the society, the development of science and

\footnotetext{
${ }^{1}$ Syarifuddin, "Pengembangan Kurikulum Lembaga Pendidikan Tinggi Islam Berbasis KKNI, Jurnal Kependidikan Islam, 2015, h-h 50-68.”
} 
technology, mandate of Undang Undang Pendidikan Tinggi (Higher Education Act) No.12, year of 2012, issues 29, Peraturan Presiden (Presidential Regulation) No.8 year of 2012 concerning the Indonesian Qualification Framework (IQF) and Peraturan Menteri Pendidikan dan Kebudayaan Republik Indonesia (Minister of Education and Culture of the Republic of Indonesia) No.73, year of 2013 concerning the Implementation of the Indonesian National Qualification Framework in the Field of Higher Education, the Islamic Higher Education Curriculum needs to be syncronized.

Based on these three regulations, the curriculum in Higher Education must contain the main profile and preferred profile and be equipped with the target of learning achievement. The master study program of Arabic Education (PBA) in UIN Raden Intan Lampung Postgraduate that newly established has sought to develop a curriculum that is oriented towards professional education. Curriculum of master study program of Arabic Education (PBA) in UIN Raden Intan Lampung Postgraduate contains the vision, mission and profile of graduates who refer to the IQF. But the question arises, whether the formulation of the Graduate Profile is in accordance with the needs of the community and stakeholders.

Therefore, researchers need to dig up the information about the perceptions of stakeholders on deeper profile formulations through systematic study, and then conduct a theoretical review of how the implications for the curriculum development of master study program of Arabic Education (PBA) in UIN Raden Intan Lampung Postgraduate can provide direction and guidance for curriculum implementers in the future will come. In the end, it can be known about the suitability of the master study program of Arabic Education (PBA) in UIN Raden Intan Lampung Postgraduate with the needs of graduates as candidates for Arabic teaching staff at the Undergraduate (S1/bachelor degree) and the needs of Graduate User Institutions.

Considering the importance of studies on stakeholders' perceptions regarding the formulation of graduate profiles as the basis for curriculum development, researchers found that there were several previous studies which also discussed similar issues. For example, Supatmi and the colleagues researched and found information about the perceptions of stakeholders and made it a basis for formulating the profile of graduates 
and became the basis for improving the quality of study programs. ${ }^{2}$ Sustainable Research on the relevance of the profile of Mathematics Education graduates at Sunan Gunung Jati Bandung with the field. Among the findings of this study are information about the importance of the relevance of graduates' profiles to the occupations. Furthermore, the research findings on the importance of the attention of Higher Education Institution Managers towards adjusting the curriculum to the needs of the vocation. ${ }^{3}$

Researcher's focus is different from the three literature studies above. They are more concerned about reviewing the suitability between learning outcomes and the suitability of alumni work with established graduate profiles. Their findings have implications for the improvement and redesign of the curriculum and its implementation to improve the quality of their study programs in the future, research is evaluative and in different fields of expertise with the object of author's study.

While the author's research focus is to dig up information on the community or stakeholders and students' needs and that will be used as a basis in formulating graduates' profiles and graduate competencies and to developing further curriculum. The author's study is constructive. This article aims to explain in detail about the perceptions of stakeholders on the formulation of the Graduates' Profile of the master study program of Arabic Education (PBA) in UIN Raden Intan Lampung Postgraduate and the implications of this perception towards curriculum document design based on IQF.

\section{Method}

The type of research that researchers use in collecting data is qualitative descriptive research with survey techniques. The survey was conducted through in-depth observation to obtain information about perceptions, opinions of stakeholders on the preparation of human resources (HR) educators that took place in the master study program of Arabic Education (PBA) in UIN Raden Intan Lampung Postgraduate. The survey was conducted on the sample of respondents selected proportionally the resulting data representing the population.

There are two types of, namely descriptive and explanatory (analytic). The

\footnotetext{
${ }^{2}$ Nunung Supratmi and Tri Wahyuni Munindrati, "Tracer Study: Profil Dan Kondisi Lulusan Program Studi S1 Pendidikan Bahasa dan Sastra Indonesia Fakultas Keguruan Dan Ilmu Pendidikan," 2014, Journal Article, Google Scholar, Accessed on December 21 2018, p. 9.

${ }^{3}$ Fahriany Fahriany, Jejen Musfah, and Azkia Muharom Albantani, "Tracer Study Profil Sosial Intelektual Alumni Program Magister FITK UIN Syarif Hidayatullah Jakarta,” 2015.
} 
author used descriptive surveys to explore respondents' perceptions of the formulation of the graduates' profile of the master study program of Arabic Education (PBA) in UIN Raden Intan Lampung Postgraduate and find out other possible profiles that they also expect.

The population that is involved in the research is stakeholders (58 students of master study program of Arabic Education (PBA) in UIN Raden Intan Lampung Postgraduate, Chairman of the bachelor degree of Arabic Education (PBA) Study Program in Lampung as a Graduate User) and partners. The study used samples that were determined using purposive sampling and cluster techniques. This means that the sample is selected by criteria and specific objectives and by region. The samples of this study are stakeholders who have an interest in the implementation of master study program of Arabic Education (PBA). They are master study program of Arabic Education (PBA) students. The postgraduate program of Raden Intan Lampung UIN is 30 students among 58 students.

Population of Stakeholders from master study program of Arabic Education (PBA) Managers located in all District and City Areas in Lampung. Samples were determined from bachelor study program of Arabic Education (PBA) in Metro and in Bandar Lampung. The sample selection is based on Region or sample area because it is not possible to conduct surveys in province. Another assumption in the determination of the sample is that the quality and experience of undergraduate education, Arabic Education (PBA) UIN Raden Intan Lampung, Bachelor study program of Arabic Education (PBA) IAIN Metro and Bachelor study program of Arabic Education (PBA) of the Sekolah Tinggi Ilmu Tarbiyah (STIT) Darul Fattah Meneng and Bachelor study program of Arabic Education (PBA) Islamic Institute Ma'arif Nahdlatul Ulama ( IAIM NU) Metro are more representative than similar Study Programs in the Kotabumi of North Lampung Regency and Pringsewu Regency. There are four Arabic Education (PBA) study programs from 6 similar study programs which are used as samples, according to this author, quite representative.

This research used a questionnaire with a Likert scale and documentation as a data collection instrument. The functions are as follows:

(1) Questionnaire, the type of questionnaire used with Likert Scale to measure stakeholders' perceptions of graduate profiles. The items in the questionnaire were developed from the variable indicators of master study program of Arabic Education 
(PBA) graduates' profile arranged in the form of statements with a four tiered scale with answers in the form of statements: Strongly Agree (SS), Agree (S), Disagree (TS), Strongly Disagree (STS) and others depend on indicators of research variables. The scoring instructions used are: a. Score 4 for answers that strongly agree (SS) b. Score 3 for answers that agree (S) c. Score 2 for answers that dissagree (TS) d. Score 1 for answers that strongly disagree (STS) ${ }^{4}$.

(2) Documentation, this method is used to obtain data on the graduates' profile of master study program of Arabic Education (PBA) in the form of curriculum drafts and other documents related to the organization of this Institute. To complete the student perception data, it is also used (3) Structured interviews, researchers use interview guides that have been provided with questions and answers to items.

\section{Result and Discussion}

\section{Research Findings}

The findings of this study can settle two research question formulations which include:

a. Perception of Stakeholders on the Formulation of Graduates Profile of master study program of Arabic Education (PBA)

Educational institutions need to adjust the graduates profile and their educational programs with the changes and demands of the field and other education stakeholders. Alignment between the expectations of stakeholders and the master study program of Arabic Education (PBA) at UIN Raden Intan Lampung Postgraduate is crucial, so that the curriculum developed and implemented will be truly relevant with stakeholder needs.

This research is considered important, and similar research is also carried out by various educational institutions in other fields. For example: the same thing was done by research in other fields such as Tracer study STAIN Samarinda graduates Islamic Education (PAI) study programs that questioned the suitability of the curriculum and its contribution to the field of work ${ }^{5}$. Also Tracer study Graduates of Chemistry in FMIPA

${ }^{4}$ Heri Retnawati, "Perbandingan Akurasi Penggunaan Skala Likert dan Pilihan Ganda Untuk Mengukur Self-Regulated Learning," Jurnal Kependidikan: Penelitian Inovasi Pembelajaran 45, no. 2 (December 14 ${ }^{\text {th } 2015), ~ h t t p s: / / d o i . o r g / 10.21831 / j k . v 45 i 2.7493, h . ~} 158$.

${ }^{5}$ Wahdatunnisa Wahdatunnisa, "Kajian Profil Lulusan STAIN Samarinda Program Studi Pendidikan Agama Islam (PAI) Tahun 2009-2013 dengan Pendekatan Tracer Study," phenomena 6, no. 1 (2014). 
UNNES that questioned the status of Chemistry Study Program graduates' jobs from 2015 to 2017 whether it is in accordance with the expected graduates Profile ${ }^{6}$.

Research conducted by Maswani aimed at assessing pedagogical, professional and personal competencies for a group of Arabic language teachers in the Tangerang area. It is known that there is a lack of conformity in teacher competencies with expectations. It was found that there were weaknesses in the Arabic language teacher of the FITK UIN syarifhidayatullah alumni, which meant that competency was not in line with the expectations of the community, so that it needed repairs and adjustments to curriculum and learning innovations. ${ }^{7}$

Stakeholder Perceptions of the profile of S2 PBA graduates The postgraduate of Raden Intan Lampung Islamic University State can be explained in the following points:

(1) Formulation of Graduates' Profiles and Student Perceptions)

The profile description of the graduates and the following indicators resulted from a decrease in the vision, mission, objectives of master study program of Arabic Education (PBA) and was characterized by the characteristics of universities that aspired to realize graduates which had the characteristics of intelligence, sprituality and integrity. The profile draft or graduate competencies are as follows:

Table 1. Competence of Graduation

\begin{tabular}{|c|c|c|}
\hline $\begin{array}{c}\text { Respondent } \\
\mathbf{3 0}\end{array}$ & $\begin{array}{c}\text { Graduates } \\
\text { profil }\end{array}$ & Competence of Graduation \\
\hline & \multirow{5}{*}{$\begin{array}{l}\text { Lecturers of } \\
\text { bachelor } \\
\text { program }\end{array}$} & $\begin{array}{l}\text { 1. Mastering the theories of education and Arabic learning integratedly } \\
\text { based on communication and technology }\end{array}$ \\
\hline & & $\begin{array}{l}\text { 2. Able to apply theories of education and Arabic learning that are } \\
\text { integrated the elements of language, proficiency and linguistics. }\end{array}$ \\
\hline & & $\begin{array}{l}\text { 3. Able to apply Arabic learning based on information communication } \\
\text { and technology. }\end{array}$ \\
\hline & & 4. Able to solve various problems in Arabic learning. \\
\hline & & $\begin{array}{l}\text { 5. Able to adapt to the global challenges in implementing Arabic } \\
\text { learning. }\end{array}$ \\
\hline
\end{tabular}

${ }^{6}$ Jumaeri et al, "Penelusuran Profil Lulusan Tahun 2015-2017 Jurusan KIMIA FMIPA UNNES." Jurnal Inovasi Pendidikan Kimia, Vol 12, No. 1, 2018, p. 2118 - 2127.

7 “(PDF) profil kompetensi lulusan program studi pendidikan bahasa arab perspektif stakeholder." 


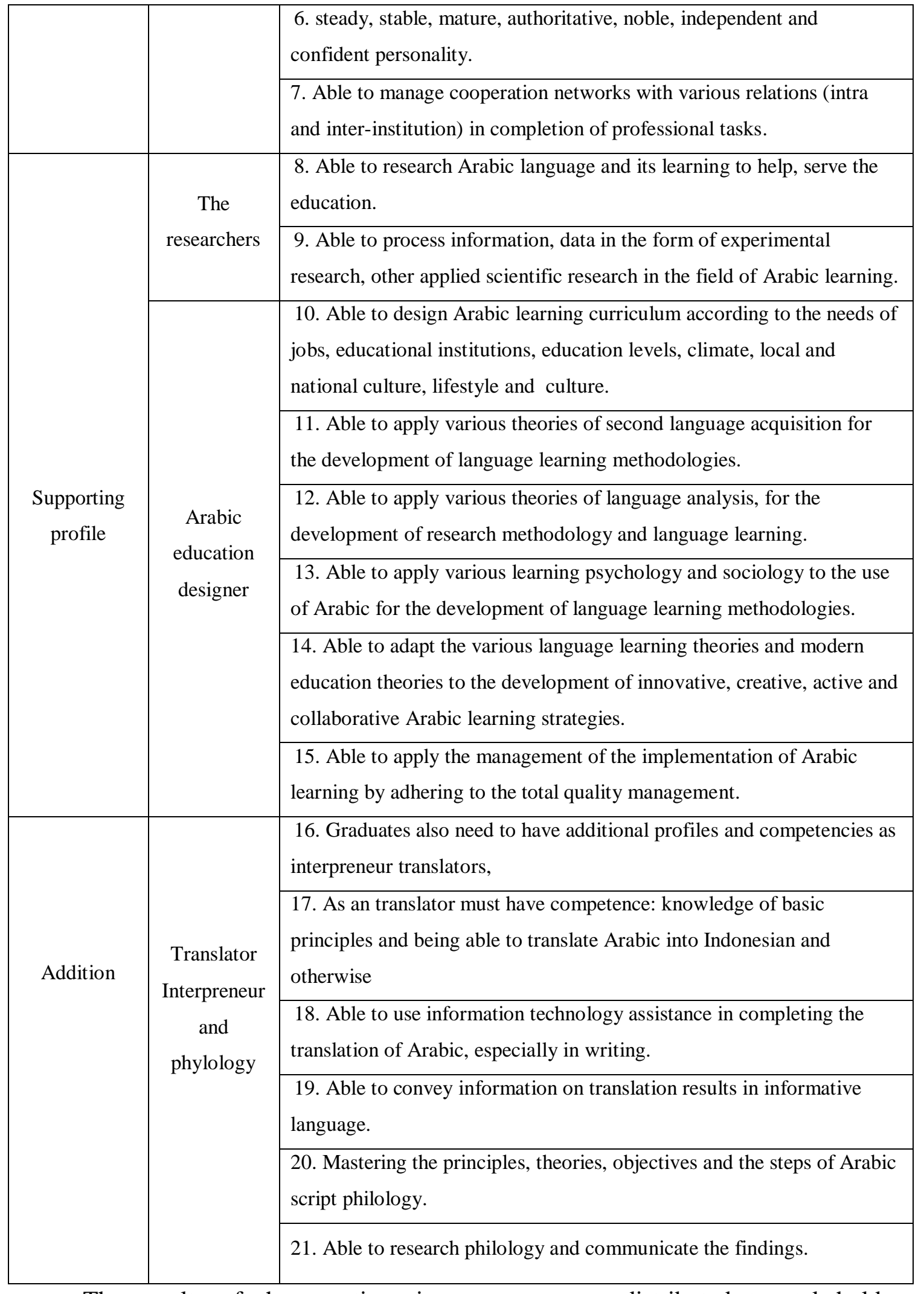

The results of the questionnaire answers were distributed to stakeholders (representatives of first and third semester student) can be seen in the following graph.

Table 2. The presentage of respondences' responses 


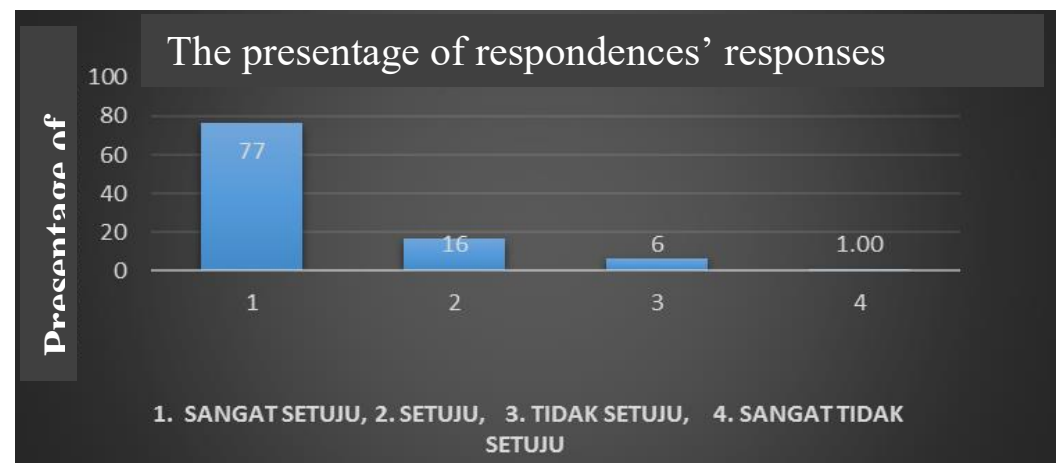

\section{Strongly Agree. 2. Agree. 3. Disagree. 4.}

The perceptions of respondents' representatives about the profile of graduates centered on the choice of answers strongly agree and agree, the number reaches $93 \%$, the remaining $6 \%$ disagree and $1 \%$ strongly disagree. It can be concluded that the formulation of graduate profiles and graduate competencies is in accordance with the expectations and needs of student participants as stakeholders.

Knowledge of perceptions, opinions of students about the profile of graduates is very important, because they are the ones who are most interested in the profile of graduates. Therefore, similar systematic research efforts have also been carried out by other researchers in other fields. For example research conducted by Faisal ${ }^{8}$, Budiman et al. ${ }^{9}$, Zulhimma ${ }^{10}$. Hill et al. Pun also describes the profile of graduates by using other terms, namely the attributes of graduates, but essentially the same as the profile of graduates, which includes knowledge, skills, expertise in their fields, attitudes, values ${ }^{11}$, which must be mastered by students so that they become ready graduates.

The profile formulation of the graduates also illustrates the learning outcomes that must be achieved by S2 PBA graduates. This is in line with the Solikhah statement that learning Out came is a statement about the learning outcomes that must be achieved and

\footnotetext{
${ }^{8}$ Faisal, "Persepsi Mahasiswa Pgsd Terhadap Implementasi Kkni Di Universitas Negeri Medan. Jurnal Inovasi Pendidikan Dan Pembelajaran Sekolah Dasar, Vol. 2 No 1, 2018;"

${ }^{9}$ Budiman, Marisa, dan Sopandi, "Tracer Study Program S1 PGPAUD Fakultas Keguruan dan Ilmu Pendidikan Universitas Terbuka, Google Scholar,2014.”

${ }^{10}$ Zulhimma, "Tracer Study Alumni Dalam Meningkatkan Mutu Akademik Di Fakultas Tarbiyah Dan Ilmu Keguruan IAIN Dangsidimpuan, Tazkir: Jurnal Penelitian Sosial Dan Keislaman, 2015, H H. 92 107."

${ }^{11}$ Hill, Walkington, dan France, "Graduate attributes: implications for higher education practice and policy," 2 April 2016.
} 
according to the needs of students and society. ${ }^{12}$ According to Nur Ali, Profile of Graduates must describe the knowledge, attitudes and skills that must be achieved by graduates ${ }^{13}$. The profile of the S2 PBA graduate Raden Intan diamond has described the main abilities as prospective Arabic language instructors, language researchers and Arabic language learning and Arabic language education designers as well as having choice competencies as translators or philology researchers.

This Author's research is in line with the opinion of Nurhadi Agung Setiyawan ${ }^{14}$ who stated that in developing the curriculum must go through empirical studies, namely to assess stakeholder needs. Based on stakeholder information, competency competencies that will be provided for learning based on a certain level of time are formulated, while the graduates' profile of a study program can be formulated. Thus the draft profile of this graduate will be determined as the basis for the revision of UIN Raden Intan Lampung's curriculum for Arabic study program in postgraduated.

The steps in developing this curriculum are also carried out in other universities in various parts of the world. Among the reports presented by Howieson et al, which emphasized the importance of the roles and responsibilities of universities and practitioners in preparing professional graduates. These issues were explored through literature reviews in several professional fields. One of the information on the research findings is that respondents generally expect the university to have the responsibility for the development of graduates in the form of mastering technical and non-technical knowledge and skills ${ }^{15}$.

Muhbib's research is also in accordance with what the researchers found, that standardization of the curriculum in the education of Arabic must be developed based on the IQF. He also noted, that curriculum development must be done humanely, integratedly and providing the real experience in the community of native language speakers ${ }^{16}$. The author believes that this humanist aspect can be integrated in teaching materials, selection of learning methods and selection of learning activities.

\footnotetext{
12 Solikhah, "KKNI dalam Kurikulum Berbasis Learning Outcomes, ."

${ }^{13}$ Ali, "Inovasi Kurikulum Lembaga Pendidikan Tenaga Kependidikan Perguruan Tinggi Agama Islam. El Hikmah,2013 diakses dari Google scholar 31-12-2018."

${ }^{14}$ Nurhadi, Agung Setiyawan, "Model Penerapan Kerangka Kualifikasi Nasional Indonesia (KKNI) Sebagai Penguatan Mutu Program Studi Pendidikan Bahasa Arab," al Mahāra: Jurnal Pendidikan Bahasa Arab, Vol.3, No.2, Desember 2017/1439H, p. 219 P-ISSN: 2477-5835/E-ISSN: 2477-5827

${ }^{15}$ Howieson dkk., "Who should teach what?"

${ }^{16}$ Muhbib Abdul Wahab, "Standarisasi Kurikulum Pendidikan Bahasa Arab Di Perguruan Tinggi Keagamaan Islam Negeri," Arabiyat: Jurnal Pendidikan Bahasa Arab dan Kebahasaaraban 3, no. 1 (28 Juni 2016), https://doi.org/10.15408/a.v3i1.3187.
} 
To achieve the profile of graduates, it is necessary to select teaching materials by considering humanist aspects, especially in terms of the selection of teaching material themes that suit the needs of graduates related to communication needs. Language is a communication tool, so language learning (including Arabic) must provide students with communication competencies. This is in line with Wekke's opinion that Arabic language teaching materials are chosen with the aim of supporting the achievement of communication competencies. ${ }^{17}$

Davies, A. \& Elder, C. in Nurhadi Agung Setiyawan states about selecting learning strategies based on IQF Curriculum is an integration of systems of value, knowledge, and skills with orientation to learner competencies. Thus, the learning method changes from Teaching Learning Methodology (TLM) to the Teaching Learning Process (TLP). In TLP learning, this gives priority to the provision of learning experiences to learners through observation (observation), discovery (inquiry), conducting associations (associating), analysis, reasoning, description, inference, evaluation, and creation. To achieve all these things, the learning method does not only use exploration strategies, elaboration, confirmation, but also observation, inquiry, analysis, reseoning, description, inference, evaluation, and creation strategies ${ }^{18}$.

(2) The perception of the graduate users and partners.

Stakeholders from graduate users are represented by the bachelor program of Arabic Education (PBA) at Faculty of Tarbiyah and Teacher Training at Raden Intan Lampung UIN and bachelor program of Arabic Education (PBA) of Sekolah Tinggi Ilmu Tarbiyah (STIT) Darul Fattah from Bandar Lampung region. Graduate users from Metro are represented by bachelor program of Arabic Education (PBA) in Tarbiyah and Teacher Training (FTIK) IAIN Metro and bachelor program of Arabic Education (PBA) of Ma'arif Nahdlatul Ulama Islamic Institute (IAIM NU) Metro.

Whereas the meaning of partners is a similar Educational Institution as the organizer of the master program of Arabic Education (PBA) in Lampung, namely the master program of Arabic Education (PBA) at the Postgraduate of Institute of the State

\footnotetext{
${ }^{17}$ Ismail Suardi Wekke, "Pendidikan Bahasa Arab Dan Konstruksi Pembelajaran Modern Di Pesantren Minoritas Muslim Indonesia."," Simposium Isu-Isu Sejarah dan Tamadun Islam (SISTI II) Institut Kajian Rantau Asia Barat (IKRAB), Universiti Kebangsaan Malaysia, 2013, h.9.

${ }^{18}$ Setiyawan, "Model Penerapan Kerangka Kualifikasi Nasional Indonesia (KKNI) Sebagai Penguatan Mutu Program Studi Pendidikan Bahasa Arab.”
} 
Islamic Religion (IAIN) Metro. This institution is considered a partner because they jointly organize services and processes for the provision of master program of Arabic Education (PBA) graduates as Human Resources (HR) to be instructors of Arabic in the Undergraduate (S1).

The purpose of extracting information from institution partner is to determine the suitability of the standardization of the formulation of graduares' profil of the master program of Arabic Education (PBA) in Raden Intan Lampung UIN. A number of users' institutions and the partner institutions have been surveyed using questionnaires, which include a number of questions about perceptions, their opinions about the suitability of graduate profile formulas and competency standards for master program of Arabic Education (PBA) graduates. It is known that the answers to all the items in the questionnaire can be seen in the following graph.

Table 3. The perception of the graduates users and partners towards the profile and the competence of graduates

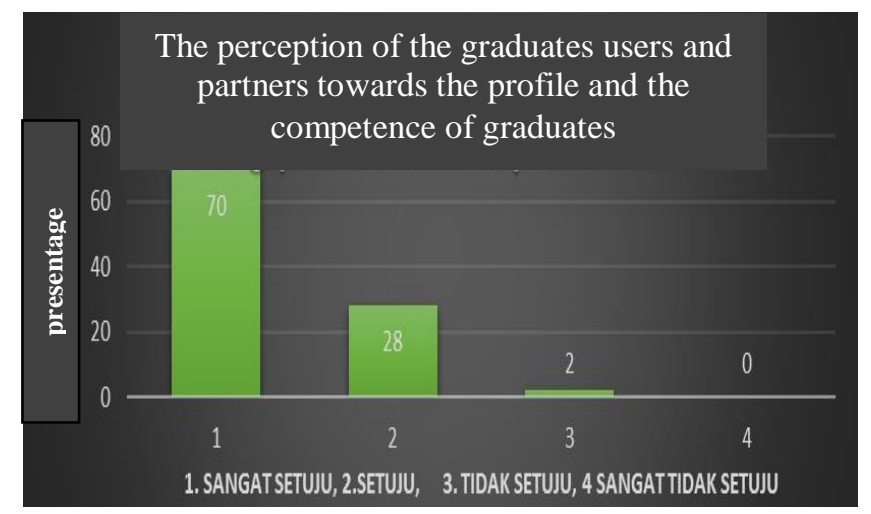

\section{Stronglv agree. 2. Agree. 3. Disagree 4. Stronglv disagree}

Data of $98 \%$ of the questionnaire answers from graduate users and partners stated that they agreed with the formulation of graduates' profiles and indicators. Their perceptions of the formula fit their needs and expectations. This data means that stakeholders (users and partners) agree and argue that the formulation of Profile of Graduates of Master Study Program of Arabic Education (PBA) UIN Raden Intan Lampung Lampung is suitable with their needs.

Efforts to gather information about views, perceptions of graduate users as stakeholders are very necessary in formulating and determining the profile of graduates of an educational institution. The goal is that we can ensure that the profile of graduates 
of educational institutions that we manage are truly in accordance with the needs of graduate user institutions. In addition, we also need to obtain opinions, perceptions of partner institutions, fellow managers of similar educational institutions so that we can ensure that the profile of graduates of educational institutions that we manage are truly in accordance with appropriate quality standards.

(3) Implications of Graduates' Profile on the Curriculum Development of Master Study Program of Arabic Education (PBA)

There is no curriculum without graduates' profile. The graduate profile statement is a testament to the academic accountability of the Study Program. The graduates' profile becomes a differentiator of one study program and other study programs. Hence, the formulation of the graduate profile has implications for the development and implementation of the curriculum, in detail explained as follows:

a. Determination of study materials and courses

In arranging the curriculum, the determination of the study material must be formulated first, then the subjects will emerge from it. In the IQF Curriculum, it has been stated that language learning material must be in line with the competency of graduates with employment. Hence, the essence of learning material should also be in accordance with graduate competencies and employment needs.

Master Study Program of Arabic Education (PBA) in UIN Raden Intan Lampung has compiled the study materials which eventually produced the several courses which can be seen in table 2 below:

Table 4. List of Master Study Program of Arabic Education (PBA) Courses)

\begin{tabular}{|c|c|c|c|}
\hline NO & CODE & COURSES & CREDITS \\
\hline 1 & \multirow{4}{*}{ MKDU } & Ad-Dirasat al-Qur'an & 2 \\
\hline 2 & & Dirasat al-Hadits & 2 \\
\hline 3 & & Hadlarat al Arab wa al-Islam & 3 \\
\hline 4 & & Falsafah al-Ulum & 2 \\
\hline 5 & \multirow{3}{*}{ MKDK } & Ilmu al-Lughah al-Ijtima'iy & 3 \\
\hline 6 & & Ilmu al-Lughah al-Nafsiy & 3 \\
\hline 7 & & Ilmu ad-Dalalah wa al-Ma'ajim & 2 \\
\hline 8 & \multirow[t]{3}{*}{ MKKU } & Bina' Manhaj al Ta'lim al-Lughah al-Arabiyah & 4 \\
\hline 9 & & Asaalibu al Lughah al Arabiyah & 3 \\
\hline 10 & & At-Taqwim at-Tarbawiy wa al-Ikhtibarat al-Lughawiyah & 2 \\
\hline
\end{tabular}




\begin{tabular}{|c|c|c|c|}
\hline 12 & & wasail Tal'im al-Lughah al-Arabiyah & 3 \\
\hline 13 & & Turuqu Tadris al Arabiyah al Ibda'iyah & 3 \\
\hline 14 & \multirow{2}{*}{ MKM } & Manahij al-Bahs al-Lughawiy wa Ta'limiha & 3 \\
\hline 15 & & Ad-Dirasat at-Taqabuliyyah wa Tahlil al-Akhta' & 2 \\
\hline 16 & MKKT & TOAFL score 475 & 0 \\
\hline & & Total & 36 \\
\hline 17 & & Publishing the journal & 0 \\
\hline 18 & & Mudarasat Khuttat al-Bahts (Proposal) & 0 \\
\hline 19 & & Seminar proposal & 0 \\
\hline 20 & & Thesis & 6 \\
\hline & & Total & 42 \\
\hline
\end{tabular}

b. Graduate Profile as the basis of Learning Design

The formulation of graduates' profile that have been obtained has implications for the design of learning activities. Learning activities need to be designed by considering the formulation of graduates' profiles so that they can be achieved maximally. In article 10, it is explained that the learning process standard is a minimum standard for educational institutions to realize learning outcomes, if they are able to achieve higher standards, it is certainly better. The standard process referred to includes: learning criteria, learning planning, implementation of learning and learning burden of students.

Learning is also expected to use a contextual approach by adjusting to the demands of competency in solving problems in the field of expertise. 19 Thematic characters are also expected to color learning within the framework of the IQF, where learning is expected to fit the scientific characteristics of the study program and be associated with real problems by applying a transdisciplinary approach.

${ }^{19}$ Zul Fahmi, "Indikator pembelajaran aktif dalam konteks Pengimplementasian pendekatan pembelajaran aktif, kreatif, Efektif, dan menyenangkan (PAKEM)," Al-Ta lim Journal 20, no. 1 (2013): 278-284. 
The learning criteria are regulated in Article 11 SNPT requires that learning occur interactively, holistically, integratedly, suitable with scientific processes, suitable with reality (contextual), effective, encouraging collaboration (collaborative), paradigm shift from teacher orientred to student orientred. The characteristics of learning are oriented to students, if learning is planned and carried out by paying attention to the development of creativity, the capacity of learners. Such orientation is very important in order to realize graduate competence. This is in line with the findings of previous research ${ }^{20}$.

It can be said as effective learning if the learning outcomes can be achieved and appropriate by prioritizing the process of mastering the materials properly and correctly by the students in a maximum time. The effectiveness of this learning becomes a necessity in every learning process. This is really crucial. Without it, the learning process will lose the spirit and essence. As other research findings reveal that active learning can spur achievement and achievement of learning goals ${ }^{21}$.

In the same thing, Raehang stated that through active learning students are expected to enable them to take responsibility for their own understanding, the most important thing is how to learn and develop awareness in individual students about learning strategies and effective thinking processes ${ }^{22}$.

Collaborative and interactive learning occurs when the learning process involves participation, interaction and collaboration between individuals to achieve mastery of attitudes, knowledge and skills. Learning outcomes are generated through two-way interaction between students and educators.

Holistic criteria can occur in learning if the process can form a comprehensive and in-depth mindset, with integrated local and national superiority and wisdom. It is expected that master level learning is integrative with the achievement of learning outcomes as a whole and inseparable through interdisciplinary and multidisciplinary approaches.

The Next, learning is expected to be scientific, in the process of achieving using a scientific approach, creating an environment and and

\footnotetext{
${ }^{20}$ Takrifin, "Membangun Interaksi Humanistik dalam Proses Pembelajaran."

${ }^{21}$ Ainak, "Implementasi Pembelajaran Bahasa Arab Model Pembelajaran Aktif, Kreatif, Efektif, dan Menyenangkan (PAKEM) di Madrasah Ibtidaiyah Sunan Pandanaran, Ngaglik, Sleman."

${ }^{22}$ Raehang, "Pembelajaran Aktif sebagai Induk Pembelajaran Koomperatif."
} 
academic culture based on academic values, norms and rules, religious values and nationalism.

Learning is also expected to use a contextual approach by adjusting to the demands of competency in solving problems in the field of expertise. Thematic characters are also expected to color learning within the framework of the IQF, where learning is expected to fit the scientific characteristics of the study program and be associated with real problems by applying a transdisciplinary approach.

The planning criteria that referred to article SNPT 10 are formations of learning planning in university in the form of Semester Lessons Plan (RPS) or other terms that mean the same. RPS is established and arranged by the lecturer independently or cooperatedly in a group of expertise in a field of science and technology for each subject presented in a study program..$^{23}$

The aspects that must be included in the Lesson plan (RPS) are the names of study programs, names and course codes, semesters, credits, names of lecturers, achievement of course learning; final ability planned at each stage of learning to meet graduate learning outcomes; study materials that match the capabilities to be achieved; learning methods; time provided to achieve ability at each stage of learning; learners' learning experiences are realized in the description of the tasks that must be done by students in one semester.

The IQF-based curriculum refers to the basis of competence ${ }^{24}$ by developing the basic potential of students. Thus, the learning process must treat the students as subjects of learning. There are several aspects that must be considered in designing learning programs and activities: First, the learning design should provide opportunities for students to search, process, find their own knowledge.

The activities of students in learning must be designed. So, they provide opportunities to develop the basic skills of the subject or material concerned.Learning design needs to consider the cultural background of the students, the value system that applies in society and their families.

${ }^{23}$ Arifin dan Rahmawati, "SNPT-and KKNI-Based Curriculum Organization."

${ }^{24}$ Kemenristekdikti "Permenristedikti Nomor 44 Tahun 2015 Tentang Standar Nasional Pendidikan Tinggi | LLDikti III," accessed on January 8 2019. Available on https://kopertis3.or.id/v5/2016/01/15/permenristedikti-nomor-44-tahun-2015-tentang-standar-nasionalpendidikan-tinggi/. 
Cultural aspects and value systems are very important to consider in curriculum development, designing learning activities is an Islamic culture and a system of Islamic values derived from noble Islamic teachings. Where the aim of Islamic teachings is to demand mankind to be noble personality, be cultured in Islam and obtain goodness in the world and the hereafter.

a. This has implications for the formulation of learning outcomes that must be achieved, namely having awareness, belief in the existence of Allah SWT and obedience to worship according to the beliefs. Require a learning process that also takes place in Islam and in the application of Islamic values in the social life of the students. This point coincides with the achievement of the learning field values and attitudes in IQF level 8 (master) ${ }^{25}$.

Second, the design of learning must be adjusted to the competency standards and profile of graduates that have been formulated. In the learning design, there are several important aspects that must be well planned, namely: setting more specific learning goals derived from the profile of graduates and achievement standards for each level of education to formulate the learning objectives of each lecture material that fits the profile.

b. The profile of graduates has implications for the implementation of learning

Competency-based learning is expected to take place in the form of interactions between educators, students, and learning resources in a particular learning environment. The learning process in each subject is carried out according to the lesson plans (RPS) with the characteristics of interactive, holistic, integrative, scientific, contextual, thematic, effective, collaborative, and student-centered.

The learning process that through curricular activities is obliged to use effective learning methods in accordance with the characteristics of the course to achieve certain abilities set in the course in the series of fulfillment of graduate learning outcomes. There is a need to transition from teacher-focused activities to learning activities that focus on students (Barrie, 2007), from students who are passive in teaching to participatory

${ }^{25}$ Admin of kemenristek, p.10 
pedagogy (Hill, 2013) and, both inside and outside the curriculum, embrace students as partners in the course of their learning process. ${ }^{26}$

Learning methods that can be chosen for learning activities include: group discussions, simulations, case studies, collaborative learning, cooperative learning, contextual learning, project-based learning, problem-based learning, or other learning methods that can effectively facilitate the fulfillment of graduate learning outcomes.

\section{c. Determination of Assessment strategies}

Assessment must be accountable, both from the technical, procedure, reporting and results. It is expected that the assessment meets the standard of assessment as a minimum criterion about the assessment of the learning process and results of students in and after learning takes place. Assessment standards include:

a).the principle of assessment, b).techniques and assessment instruments,

c).assessment procedures, d).report assessment, and f).determination of graduation of students.

The principle of assessment is based on educative, authentic, objective, accountable and transparent principles that are carried out in an integrated manner. The educational principle aims to motivate students to be able to:

(a) improve the way of learning; and

(b) achieving learning outcomes. The authentic principle is the principle of resultsoriented assessment and continuous learning processes that describe the ability of students when the learning process takes place.

The objective principle requires assessment based on the standards that is agreed upon between lecturers and students free from the influence of subjectivity. The accountable principle can be proven if the assessment is carried out in accordance with procedures and clear criteria, agreed upon at the beginning of the lecture, and understood by students. Transparency of assessment is proven through procedures and assessment results that can be accessed by all stakeholders.

The object of the assessment includes the assessment of attitudes, mastery of knowledge, general skills, and special skills by using one or a combination of sharing assessment techniques and instruments. The final results of the assessment are the accumulated results of the assessment. Learning assessment is carried out during the

${ }^{26}$ Hill, Walkington, dan France, "Graduate attributes: implications for higher education practice and policy," 2 April 2016. 
process to see the progress of the results in several stages of learning. The strongest evidence of achievement of graduate profiles (Graduate Attributes) is the explicit assessment of learning outcomes (Hughes) derived from graduate profiles. ${ }^{27}$

This assessment process is crucial because it aims to examine, review, give direction and input to students will be a benchmark for achievement of capabilities. The assessment process that is considered appropriate in the IQF curriculum-based learning is the Performance Assessment (or Authentic Assessment), which is an assessment that includes three basic activities, namely: assignment of assignments, students showing their performance, assessed based on certain indicators called Rubrics. Assessment techniques consist of observation, participation, performance, written tests, oral tests, and questionnaires. Process assessment instruments in the form of rubric and portfolio or design work.

Purpose of Evaluation is to give judgment and decisions regarding values. Evaluation is a process or action, both processes are carried out to give meaning or value. Evaluation of a process, evaluation consists of: first collecting data and information about achieving student learning outcomes, second making decisions about student learning outcomes based on information that has been obtained .

Fachruddin Azmi, et al. stated that the criteria for student learning success include achievement: cognitive, affective and psychomotor aspects ${ }^{28}$. Cognitive aspects relate to students 'intellectual and intellectual abilities, affective aspects related to the assessment of students' attitudes and interests in the subjects and the learning process. Psychomotor aspects consist of several competencies that must be achieved both the level of mastery of the initial motion, the level of routine motion and overall mobility.

As a form of curriculum that requires the achievement of competencies, instruments and forms of assessment must be balanced both test and non-test in accordance with the evaluation function as a formative and summative function. Both evaluation functions are crucial as a guaranty of curriculum quality.

\footnotetext{
${ }^{27}$ Hill, Walkington, dan France.

${ }^{28}$ Pohan, "Pelaksanaan Pembimbingan Belajar Aspek Kognitif, Afektif Dan Psikomotorik Siswa Di Madrasah Ibtidaiyah Swasta Amal Shaleh Medan."
} 


\section{Conclusion}

Stakeholders (the users, students) strongly agree on the profile of Master Study Program of Arabic Education (PBA) graduates, and they argue that the profile of graduates is suitable for their needs. Profile of Master Study Program of Arabic Education (PBA) UIN Raden Intan Lampung graduates includes main profiles as Arabic Language Teachers at undergraduate program, supporting profiles as Arabic Language learning designers and researchers, optional / additional profiles as philologists and Arabic translators. The formulation of the Graduate Profile produced based on IQF has implications for the formulation of graduate competency standards, the determination of study materials, the design of learning and evaluation is also based on the IQF. The findings of this research suggest that the development, implementation and evaluation of the curriculum and the implementation of Master Study Program of Arabic Education (PBA) should be carried out based on the IQF by meeting the National Higher Education standards.

\section{References}

Abdul Wahab, Muhbib. "Standarisasi Kurikulum Pendidikan Bahasa Arab di Perguruan Tinggi Keagamaan Islam Negeri." Arabiyat: Jurnal Pendidikan Bahasa Arab dan Kebahasaaraban 3, no. 1 (28 Juni 2016). https://doi.org/10.15408/a.v3i1.3187.

admin. "Permenristedikti Nomor 44 Tahun 2015 Tentang Standar Nasional Pendidikan Tinggi | LLDikti III.” Diakses 8 Januari 2019. https://kopertis3.or.id/v5/2016/01/15/permenristedikti-nomor-44-tahun-2015tentang-standar-nasional-pendidikan-tinggi/.

Ainak, Roihanatul. "Implementasi Pembelajaran Bahasa Arab Model Pembelajaran Aktif, Kreatif, Efektif, dan Menyenangkan (PAKEM) di Madrasah Ibtidaiyah Sunan Pandanaran, Ngaglik, Sleman.” Unpublished Paper. Yogyakarta: UIN [Universitas Islam Negeri] Sunan Kalijaga, 2009.

Ali, Nur. "Inovasi Kurikulum Lembaga Pendidikan Tenaga Kependidikan Perguruan Tinggi Agama Islam.” el-hikmah, 2013.

Arifin, Zainal, dan Laili Etika Rahmawati. "SNPT-and KKNI-Based Curriculum Organization," 2016. 
Budiman, Muman Hendra, Marisa Marisa, dan Agus Tatang Sopandi. "Tracer Study Program S1 PGPAUD Fakultas Keguruan dan Ilmu Pendidikan Universitas Terbuka," 2014.

Fahriany, Fahriany, Jejen Musfah, dan Azkia Muharom Albantani. “Tracer Study Profil Sosial Intelektual Alumni Program Magister FITK UIN Syarif Hidayatullah Jakarta," 2015.

Faisal, Faisal. "Persepsi Mahasiswa PGSD Terhadap Implementasi KKNI di Universitas Negeri Medan.” Jurnal Inovasi Pendidikan dan Pembelajaran Sekolah Dasar 2, no. 1 (2018).

Hill, Jennifer, Helen Walkington, dan Derek France. "Graduate attributes: implications for higher education practice and policy." Journal of Geography in Higher Education 40, no. 2 (2 April 2016): 155-63. https://doi.org/10.1080/03098265.2016.1154932.

—. "Graduate attributes: implications for higher education practice and policy." Journal of Geography in Higher Education 40, no. 2 (2 April 2016): 155-63. https://doi.org/10.1080/03098265.2016.1154932.

Howieson, Bryan, Phil Hancock, Naomi Segal, Marie Kavanagh, Irene Tempone, dan Jenny Kent. "Who should teach what? Australian perceptions of the roles of universities and practice in the education of professional accountants." Journal of Accounting Education 32, no. 3 (2014): 259-275.

“(PDF) Profil Kompetensi Lulusan Program Studi Pendidikan Bahasa Arab Perspektif Stakeholder.” ResearchGate. Diakses 19 Desember 2018. http://dx.doi.org/10.15408/a.v3i2.4163.

Pohan, Nurbiah. "Pelaksanaan Pembimbingan Belajar Aspek Kognitif, Afektif dan Psikomotorik Siswa di Madrasah Ibtidaiyah Swasta Amal Shaleh Medan." Attazakki: Jurnal Kajian Ilmu Pendidikan Islam dan Humaniora 1, no. 2 (2017): $15-28$.

Raehang, Raehang. "Pembelajaran Aktif sebagai Induk Pembelajaran Koomperatif." AlTa'dib 7, no. 1 (2014): 149-167.

Retnawati, Heri. "Perbandingan Akurasi Penggunaan Skala Likert dan Pilihan Ganda untuk Mengukur Self-Regulated Learning.” Jurnal Kependidikan: Penelitian Inovasi Pembelajaran 45, no. 2 (14 Desember 2015). https://doi.org/10.21831/jk.v45i2.7493. 
Setiyawan, Agung. "Model Penerapan Kerangka Kualifikasi Nasional Indonesia (KKNI) Sebagai Penguatan Mutu Program Studi Pendidikan Bahasa Arab." Al Mahāra: Jurnal Pendidikan Bahasa Arab 3, no. 2 (2017): 217-236.

Solikhah, Imroatus. "KKNI dalam Kurikulum Berbasis Learning Outcomes.” LINGUA: Journal of Language, Literature and Teaching 12, no. 1 (2015): 1-22.

Supratmi, Nunung, dan Tri Wahyuni Munindrati. "Tracer Study: Profil dan Kondisi Lulusan Program Studi S1 Pendidikan Bahasa dan Sastra Indonesia Fakultas Keguruan dan Ilmu Pendidikan.” tidak dipublikasikan, 2014.

Syarifuddin, Ahmad. "Pengembangan Kurikulum Lembaga Pendidikan Tinggi Islam Berbasis KKNI.” JURNAL KEPENDIDIKAN ISLAM 5, no. 1 (2015): 50-68.

Takrifin, Ahmad. "Membangun Interaksi Humanistik dalam Proses Pembelajaran." Edukasia Islamika 7, no. 1 (2013).

Wahdatunnisa, Wahdatunnisa. "Kajian Profil Lulusan STAIN Samarinda Program Studi Pendidikan Agama Islam (PAI) Tahun 2009-2013 dengan Pendekatan Tracer Study." Jurnal Fenomena 6, no. 1 (2014).

Wekke, Ismail Suardi. "Pendidikan Bahasa Arab dan Konstruksi Pembelajaran Modern Di Pesantren Minoritas Muslim Indonesia.".” Simposium Isu-Isu Sejarah dan Tamadun Islam (SISTI II) Institut Kajian Rantau Asia Barat (IKRAB), Universiti Kebangsaan Malaysia, 2013.

Zulhimma, Zulhimma. "Tracer Study Alumni dalam Meningkatkan Mutu Akademik di Fakultas Tarbiyah dan Ilmu Keguruan IAIN Dangsidimpuan.” Tazkir: Jurnal Penelitian Ilmu-Ilmu Sosial Dan Keislaman 1, no. 2 (2015): 92-107. 